\title{
EVALUATION OF THE MICROCLIMATE DURING OLIVE OIL EXTRACTION OPERATIONS INSIDE OLIVE MILLS
}

\author{
Vittorio Panaro, Simone Pascuzzi, Francesco Santoro
}

\section{Introduction}

The process of oil extraction within an oil mill involves the workers being exposed to a number of risks: movement of loads, specific postures, high level of noise etc.; among these, one of the least studied is that of the microclimatic conditions within the workplace $[2,3]$. By the term "microclimate" we mean the climatic variables within the workplace which cause heat exchanges for those working there $[1,5]$.

A comfortable microclimate produces, when we talk of temperature and humidity, a feeling of satisfaction in most people; inappropriate microclimatic conditions, however, even when they do not have pathological effects, can cause physical discomfort and induce lower productivity and situations of danger.

So-called "microclimatic wellbeing" is reached in a simultaneous condition of global comfort, or heat equilibrium of the whole body, and local comfort, or heat equilibrium between the different parts of the body.

The law to which we refer for matters of climatic conditions in work environments is art. 11 and 13 of the D.P.R. 303/1956, updated by D.L. 626 of 1994; from these we can see that control of the microclimate in work environments is important for worker safety and the employer is responsible for risk evaluation in connection with inadequate control of environmental conditions.

It's important to specify that the evaluation of microclimatic risk is carried out on the basis of the distinction between "moderate environments" and "extremely hot or cold environments" [6, 12].

Some authors affirm that the area of oil mills where extraction takes place can be considered "a

\section{Paper received 16.06.2006; accepted 11.05.2007}

VitTorio Panaro, engineer full professor, SimONE PASCUZZI, engineer associate professor, FRANCESCO SANTORO, engineer researcher, Pro.Ge.S.A. Department - University of Bari.

Study supported by a grant from MIUR PRIN 2003, project: "Quality of work and safety in agro-industrial environments: identification of main risk factors and definition of guidelines", national coordinator Prof. Giorgio Zoppello.

Each of the authors contributed in equal parts to this work. thermally moderate environment" since the productive processes do not involve particularly stressful thermal conditions; this type of environment, therefore should not affect the health of workers and the evaluation of the microclimate could be limited on the one hand to comparing data on temperature and humidity with standard data from the sector, and on the other taking into consideration the subjective feelings of the workers in the various areas [7].

However, a more accurate study of the microclimate in these environments, based on data from measuring instruments, can be carried out referring to the European Standard UNI EN ISO 7730:2006.

This Standard bases the procedure for measuring microclimatic comfort in a thermally moderate environment on the direct relationship existing between the heat balance of a person and the corresponding feeling of heat or cold; it is known that the human organism is in equilibrium when the power of the heat generated inside is equal to that exuded into the environment. The system of thermo-regulation, based on external climatic conditions, on the metabolism and on type of clothing, tries to automatically modify the body temperature and the secretion of perspiration to maintain this thermal equilibrium.

The optimum condition is at this point of heat equilibrium, and feelings of growing discomfort are associated with an increased distance from this point of equilibrium.

The heat balance is calculated on the basis of environmental parameters (air temperature, mean radiating temperature, air speed and humidity) and of parameters connected to metabolism, activity, thermal resistance of clothes. This heat balance is strictly related to the so-called index of the mean quality of the microclimatic conditions PMV (Predicted Mean Vote), expressed on a seven point thermal sensation scale shown in Tab. 1 [14].

Since it is talking about a mean value, PMV takes into account the existence of individual variability; even in a group of people exposed to the same microclimatic conditions, it is, therefore, impossible to characterise an ideal situation that is valid for all.

Consequently, we link a second index to PMV, 


\begin{tabular}{|c|l|}
\hline PMV & Sensation \\
\hline-3 & Cold \\
\hline-2 & Cool \\
\hline-1 & Slightly cool \\
\hline 0 & Neutral \\
\hline+1 & Slightly warm \\
\hline+2 & Warm \\
\hline+3 & Hot \\
\hline
\end{tabular}

TABLE 1 - Seven-point thermal sensation scale.

called PPD (Predicted Percentage of Dissatisfied), which establishes a percentage of people who will feel dissatisfied with the microclimatic conditions under study.

The PMV and PPD indexes, referring to global comfort, synthesise all the information necessary to determine and interpret well-being in a thermally moderate environment.

Conditions of local discomfort which, as already stated, originate from an undesired cooling or heating of a part of the body, are generally caused by: a. drafts, b. high temperature difference between head and ankles, c. floors that are too hot or too cold, d. great differences between radiating temperatures. The Standard allows us to determine the risks connected to these types of discomfort, which affects mainly people who have a sedentary or light activity.

On the basis of the above, we examined some of the most representative olive mills in the Puglia Region $[8,9]$, in terms of quality and productivity, and inside these, during the process of oil extraction, we measured environmental temperature and humidity and the thermal sensations felt by the workers; the analysis gave a statistic picture including the degree of thermal fatigue of the workers in the oil mills.

Using the technical Standard illustrated above, we later carried out a study of the global comfort conditions in the work areas of the oil mills during oil extraction, creating a numerical code in MATLAB language able to calculate the PMV and PPD indexes and to automatically create graphs for the analysis of thermal sensations and the discomfort of those present inside the working areas.

This research is the continuation of others already carried out by the same authors and granted by MIUR, with the aim of establishing the risks and the forms of prevention within the Apulian olive oil production system $[10,11]$.

\section{Materials and methods}

\subsection{Instrumental surveys}

As already stated, we measured environmental temperature and relative humidity during extraction operations in two oil mills with discontinuous cycle (indicated below with the letters A-B), with produc- tive capacity varying from 300 to $1200 \mathrm{~kg} / \mathrm{h}$ of olive oil, and three oil mills with continuous cycle (C-D-E), with production above $1500 \mathrm{~kg} / \mathrm{h}$; the mills studied can be considered as representative, in terms of quality and productivity, of the Puglia Region [9].

For each of these oil mills we analysed the layout, essential to find the areas where the environmental parameters can be considered uniform (mean radiating temperature, relative humidity, temperature and air speed). At the centre of each of these "homogeneous areas" we placed a LSI microclimate monitoring station to capture data, with the following probes:

a. hot-wire anemometer BS-V101 measurement range: $0 \div 50 \mathrm{~m} / \mathrm{sec}$, precision: $\pm 4 \mathrm{~cm} / \mathrm{sec}(0 \div 1$ $\mathrm{m} / \mathrm{sec}$ ) $4 \%>1 \mathrm{~m} / \mathrm{sec}$, response time: $10 \mathrm{~ms}$;

b. psychrometric probe with forced ventilation and distilled water tank BSU102, for measuring dry and wet temperatures, relative humidity, dew point (ISO7726 standards) - temperature measurement range: $-5 \div+60{ }^{\circ} \mathrm{C}$, humidity measurement range: $0 \div 100 \%$, temperature accuracy: $<0.35^{\circ} \mathrm{C}$, humidity accuracy $\left(\mathrm{T}=15 \ldots 45^{\circ} \mathrm{C}\right): 2 \%$, response time: 1.5 $\min$;

c. black globe thermometric probe in black opaque copper BST131 (reflection <2\% ASTM 97-55) to measure the average radiant temperature (ISO7726 standard) for measuring mean radiating temperature (regulations ISO7726) - measuring range: $40 \div 80^{\circ} \mathrm{C}$, accuracy: $<0.35^{\circ} \mathrm{C}$, response time: 20 min.

The data obtained by the various probes was sent to a LSI six inputs multiple data acquisition device, mod. "BabucM" BSA020, with 5000 samples memory (32 $\mathrm{Kb}$ EEPROM), and then to a personal computer for elaboration.

Since the values of the climatic parameters were mainly constant throughout the working day it was decided to limit the testing period to one hour for each "homogeneous area".

We basically considered two "homogeneous areas" for the various oil mills: the storage area for the olives, in an open area connected to the outside, and the internal ones where the extraction process takes place (milling area).

\subsection{Theoretical study}

For the theoretical study of the microclimate we established the PMV using the following formulae from UNI EN ISO 7730:

$$
\begin{aligned}
& \mathrm{PMV}=\left(0.303 \cdot \mathrm{e}^{-0.060 \mathrm{M}}+0.028\right) . \\
& \cdot\left\{(\mathrm{M}-\mathrm{W})+\mathrm{Q}_{1}+\mathrm{Q}_{2}+\mathrm{Q}_{3}\right\}
\end{aligned}
$$

with:

$$
\begin{aligned}
& Q_{1}=-3.05-10^{-3} \cdot\left[5733-6.99 \cdot(M-W)-p_{2}\right]- \\
& -0.42 \cdot[(M-W)-58.15] \\
& \quad Q_{2}=-1.7 \cdot 10^{-5} \cdot M \cdot\left(5867-p_{2}\right)
\end{aligned}
$$




$$
\begin{aligned}
& \mathrm{Q}_{3}=-1.4 \cdot 10^{-3} \cdot \mathrm{M} \cdot\left(34-\mathrm{t}_{2}\right)- \\
& -3.96 \cdot 10^{-3} \cdot \mathrm{f}_{\mathrm{cl}} \cdot\left[\left(\mathrm{t}_{\mathrm{ct}}+273\right)^{4}-\left(\mathrm{t}_{\mathrm{r}}+273\right)^{4}\right]- \\
& -\mathrm{f}_{\mathrm{sl}} \cdot \mathrm{h}_{\mathrm{t}} \cdot\left(\mathrm{t}_{\mathrm{ct}}-\mathrm{t}_{\mathrm{a}}\right) \\
& \mathrm{t}_{\mathrm{cl}}=35.7-2.810^{2} \cdot(\mathrm{M}-\mathrm{W})-\mathrm{I}_{\mathrm{s}} . \\
& \left\{\left\{3.9610^{-2}-f_{c i} \cdot\left[\left(t_{c t}+273\right)^{4}-\left(t_{r}+273\right)^{4}\right]+\right.\right. \\
& \left.+\mathrm{f}_{\mathrm{c}} \cdot \mathrm{h}_{\mathrm{c}} \cdot\left(\mathrm{t}_{\mathrm{ct}}-\mathrm{t}_{\mathrm{s}}\right)\right\} \\
& \mathrm{h}_{\mathrm{c}}=2.38\left|\mathrm{t}_{\mathrm{el}}-\mathrm{t}_{\mathrm{s}}\right|^{0.25}
\end{aligned}
$$

se

$$
2.38\left|\mathrm{t}_{\mathrm{st}}-\mathrm{t}_{\mathrm{s}}\right|^{0.25}>12.1 \cdot \sqrt{\mathrm{v}_{s}}
$$

oppure

$$
\mathrm{h}_{q}=12 \cdot 1 \cdot \sqrt{\mathrm{v}_{u}}
$$

se

$$
\begin{gathered}
2.38\left|\mathrm{t}_{\mathrm{cl}}-\mathrm{t}_{2}\right|^{0.35}\left(12.1 \cdot \sqrt{\mathrm{v}_{\mathrm{ur}}}\right. \\
\mathrm{f}_{\mathrm{sl}}=1.00+1.290 \cdot \mathrm{I}_{\mathrm{s}}
\end{gathered}
$$

se

$$
\mathrm{I}_{\mathrm{d}} \leq 0.078
$$

oppure

se

$$
f_{c 1}=1.05+0.645 \cdot I_{d}
$$

$$
\mathrm{I}_{\mathrm{d}}>0.078
$$

where: $\mathrm{M}$ - specific metabolic power $\left[\mathrm{W} / \mathrm{m}^{2}\right] ; \mathrm{W}-$ specific power relative to working activity $\left[\mathrm{W} / \mathrm{m}^{2}\right] ; \mathrm{I}_{\mathrm{cl}}$ - thermal resistance of clothing $\left[\mathrm{m}^{2} \mathrm{~K} / \mathrm{W}\right] ; \mathrm{f}_{\mathrm{cl}}-$ ratio of clothed human body area to bare human body area; $\mathrm{t}_{\mathrm{a}}$ - air temperature $\left[{ }^{\circ} \mathrm{C}\right] ; \mathrm{t}_{\mathrm{r}}$ - mean radiating temperature $\left[{ }^{\circ} \mathrm{C}\right] ; \mathrm{v}_{\mathrm{ar}}$ - relative velocity of air to human body $[\mathrm{m} / \mathrm{s}] ; \mathrm{p}_{\mathrm{a}}-$ partial pressure of water vapour $[\mathrm{Pa}] ; \mathrm{h}_{\mathrm{c}}-$ coefficient of convection heat transfer $\left[\mathrm{W} /\left(\mathrm{m}^{2} . \mathrm{K}\right)\right]$; $\mathrm{t}_{\mathrm{cl}}$ - surface temperature of clothing $\left[{ }^{\circ} \mathrm{C}\right]$.

The afore mentioned Standard considers the indexes obtained from (1) for PMV values in the $-2 \div+2$ range as reliable and recommends the following ranges for the relative parameters: $M=46 \div 232$ $\left[\mathrm{W} / \mathrm{m}^{2}\right](0.8 \div 4[\mathrm{met}]) ; \mathrm{I}_{\mathrm{cl}}=0 \div 0.310\left[\mathrm{~m}^{2} \mathrm{~K} / \mathrm{W}\right](0 \div 2$ [clo]); $\mathrm{t}_{\mathrm{a}}=10 \div 30\left[{ }^{\circ} \mathrm{C}\right] ; \mathrm{t}_{\mathrm{r}}=10 \div 40 \quad\left[{ }^{\circ} \mathrm{C}\right] ; \mathrm{v}_{\mathrm{ar}}=0 \div 1$ $[\mathrm{m} / \mathrm{s}] ; \mathrm{p}_{\mathrm{a}}=0 \div 2700[\mathrm{~Pa}]$, that is relative humidity - ur - in the range $30 \div 70 \%$.

Values for these parameters outside these ranges can be used to determine the PMV index which, in this case will only represent an approximate measurement of the microclimatic environmental conditions.

The UNI EN ISO 7730:2006 Standard states that equations (5) and (6) for the calculation of the surface temperature of clothing $t_{c l}$ and the coefficient of convection heat transfer $h_{c}$ respectively are solved with iterative methods.

Given PMV $=0$, equation (1) allows us to determine the combinations between the environmental parame- ters and those relative to the metabolism, to activity and to clothing that give the workers the feeling of thermal neutrality.

The algorythm for the calculation of PPD, that predicts the percentage of individuals within a numerous group who are thermally dissatisfied, is:

$$
\mathrm{PPD}=100-95 \cdot \mathrm{e}^{-\left(0.03353 \cdot \mathrm{PMV}^{4}+0.2179 \cdot \mathrm{PMV}^{2}\right)}
$$

\subsection{Software code}

The algorithms above were implemented in a software code in MATLAB language set up by the authors, that allows the calculation of PMV and PPD and the automatic creation of diagrams of these indexes on the basis of the various parameters that influence the thermal balance of the human organism.

The input data was:

- microclimatic parameters (temperature $\mathrm{t}_{\mathrm{a}}$ and air speed $\mathrm{v}_{\mathrm{ar}}$, relative humidity ur, radiating temperature $\mathrm{t}_{\mathrm{r}}$ );

- parameters relative to the characteristics of the workers (specific metabolic power $\mathrm{M}$, specific power connected to the work done $\mathrm{W}$, thermal resistance of the clothing $\mathrm{I}_{\mathrm{cl}}$ ).

The programme initially calculates the partial pressure of the water vapour present in the air $p_{a}$, which is determined on the basis of the relative humidity, of the air temperature and of the saturation pressure of the water vapour $\mathrm{p}_{\mathrm{sat}}$ using the following Technical Physics formulae:

$$
\begin{gathered}
\mathrm{p}_{\mathrm{xal}}=611.85 \cdot \mathrm{e}^{\frac{17.5021_{0}}{245.9+1_{4}}} \\
\mathrm{P}_{2}=\frac{\mathrm{ur} \cdot \mathrm{p}_{\mathrm{ea}}}{100}
\end{gathered}
$$

Formulae (8) and (9) therefore allow the calculation of parameter $f_{c l}$.

The clothing surface temperature $t_{c l}$ and the coefficient of convection heat transfer $h_{c}$ are calculated by successive approximation, applying the iterative algo-

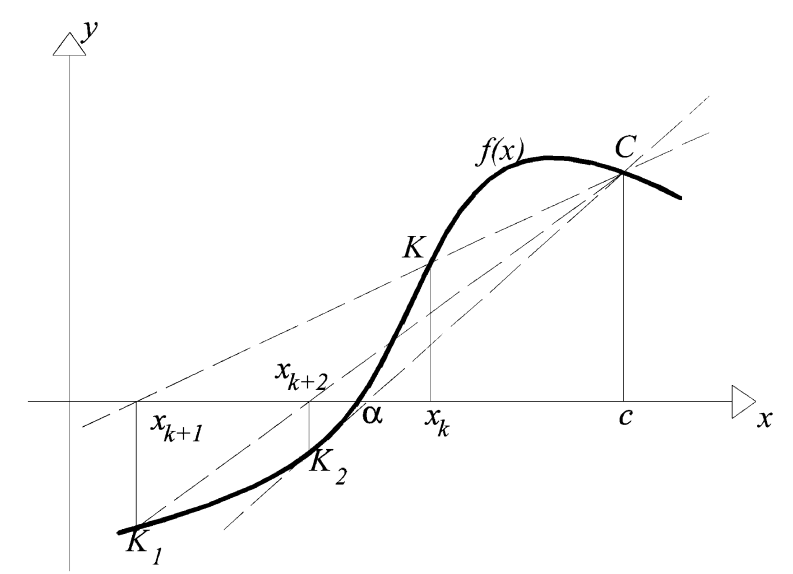

Fig. 1 - "False position" method of convergence. 
rithm of numerical calculation, called "false position", which has the following recursive formulation [4]:

$$
x_{k+1}=\frac{c \cdot f\left(x_{k}\right)-x_{i} \cdot f(c)}{f\left(x_{k}\right)-f(c)}
$$

With this algorithm, to find the root of the equation $y=f(x)$ (for example " $\alpha$ " in Fig. 1), we assume an initial approximate solution $x_{k}$, corresponding to point $K\left(x_{k} f\left(x_{k}\right)\right)$ on the curve. We also consider another point $C(c, f(c))$ on the same curve.

The line joining $C$ and $K$ crosses the axis $x$ at point $x_{k+1}$, which represents a further approximation of the root $\alpha$ we are seeking. We then take the point $K_{I}\left(x_{k+1} f\left(x_{k+1}\right)\right)$; the line joining $C$ and $K_{l}$ crosses axis $x$ at point $x_{k+2}$, another approximation of the root $\alpha$ we are seeking. The procedure is repeated with point $K_{3}$ and the line joining $C$ and $K_{3}$. The iterative process finishes when two successive solutions $\left(x_{i}, x_{i+1}\right)$ of the equation $y=f(x)$ differ with a value inferior to a preestablished quantity.

Having calculated values $t_{c l}$ and $h_{c}$ and solved equations (4), (3), (2), (1) we find PMV; finally (10) allows us to give a value to PPD.

\section{Results and discussion}

Figures 2 and 3 show respectively, as histograms, air temperature and radiating temperatures registered in the oil mills under study. Figures 4 and 5 are a diagrammatic representation of the air speeds and the relative humidity in the same mills.

From these graphs it is obvious that the least com-
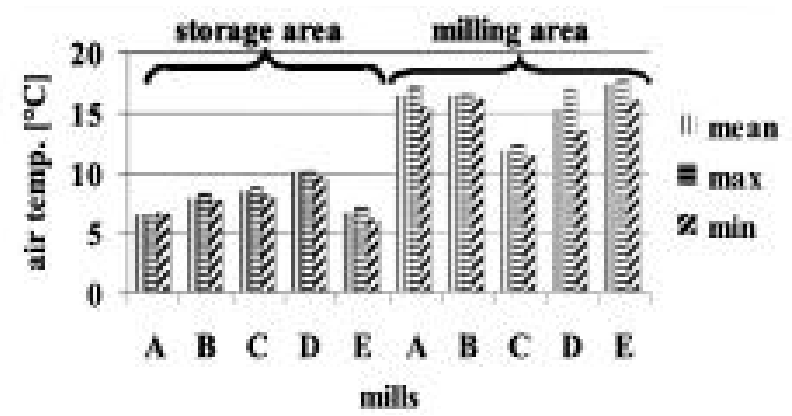

Fig. 2 - Air temperatures registered in the mills.

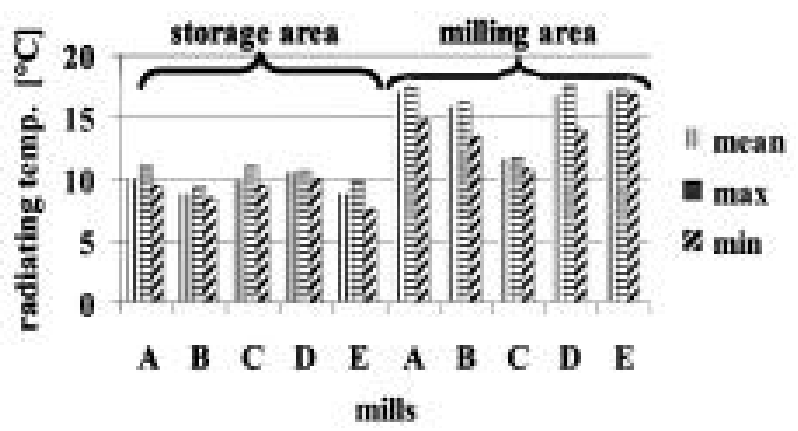

Fig. 3 - Radiating temperatures registered in the mills. fortable climatic areas are the storage points for the olives which, as already stated, are draughty because they are connected to the outside; the mean environmental parameters registered are as follows: $\mathrm{t}_{\mathrm{a}}=7.7$ $\left[{ }^{\circ} \mathrm{C}\right], \mathrm{t}_{\mathrm{g}}=9.5\left[{ }^{\circ} \mathrm{C}\right], \mathrm{v}_{\mathrm{ar}}=0.3[\mathrm{~m} / \mathrm{s}], \mathrm{ur}=68 \%$.

The climatic values in the areas for oil extraction are much more acceptable and create conditions of environmental wellbeing; the mean climatic parameters were as follows: $\mathrm{t}_{\mathrm{a}}=15.3\left[{ }^{\circ} \mathrm{C}\right], \mathrm{t}_{\mathrm{g}}=15.5\left[{ }^{\circ} \mathrm{C}\right], \mathrm{v}_{\mathrm{ar}}$ $=0.1[\mathrm{~m} / \mathrm{s}]$, ur $=61 \%$.

The calculations for the PMV indexes were made on the basis of the environmental values registered and assuming the following mean parameters for the workers [14]:

- specific metabolic power $\mathrm{M}=116\left[\mathrm{~W} / \mathrm{m}^{2}\right](2,0$ [met]), corresponding to an average level of activity carried out standing up;

- specific power relative to working activity $\mathrm{W}=0$ $\left[\mathrm{W} / \mathrm{m}^{2}\right]$;

- thermal resistance of work clothing $\mathrm{I}_{\mathrm{cl}}=0.170$ $\left[\mathrm{m}^{2} \mathrm{~K} / \mathrm{W}\right](1.10$ [clo]) (clothing made up of shortsleeved and short-legged underwear, shirt, trousers, overalls, socks, shoes).

Figures 6 and 7 show, respectively, the results of the calculations of PMV and PPD; in the graphs the histograms with vertical lines refer to the olive storage areas, while those with horizontal lines refer to the milling areas.

These diagrams basically confirm what the workers declared when interviewed, that is a situation of discomfort in the olive storage areas; in these areas the PMV is always negative with a sensation of greater or lesser degrees of cold. The nearest the PMV

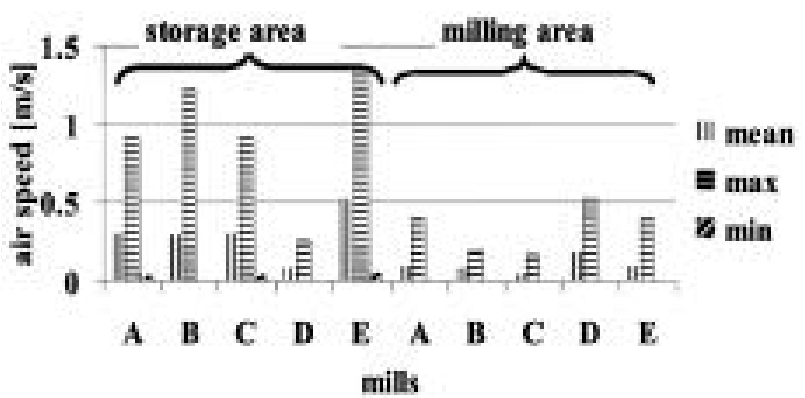

Fig. 4 - Air speeds registered in the mills.

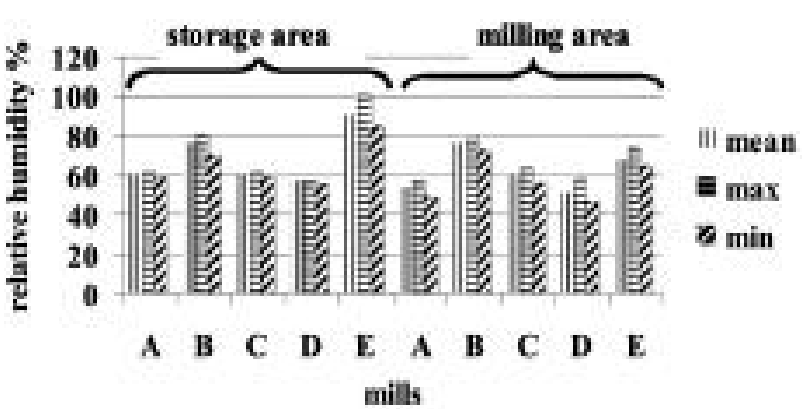

Fig. 5 - Relative humidity registered in the mills. 


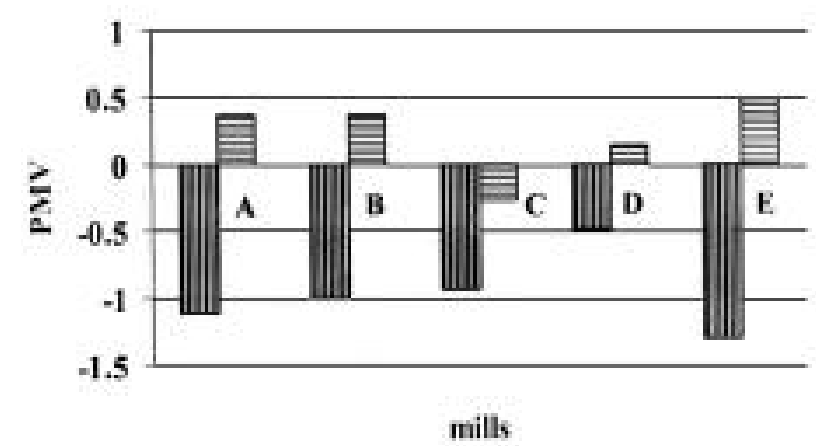

Fig. 6 - PMV indexes (histograms with vertical lines: olive storage areas; histograms with horizontal lines: milling areas).

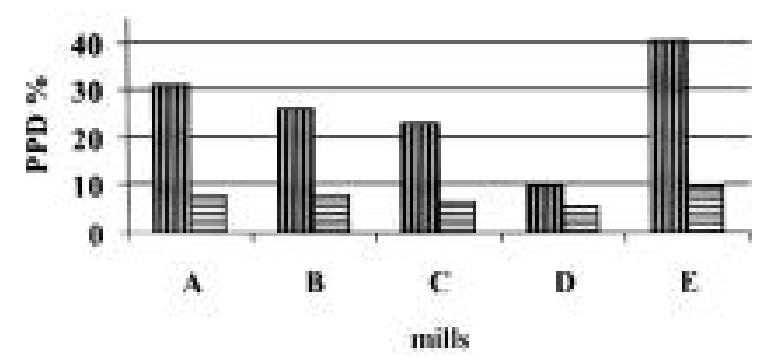

Fig. 7 - PPD indexes (histograms with vertical lines: olive storage areas; histograms with horizontal lines: milling areas).

index came to neutral conditions was in the continuous cycle oil mill $\mathrm{D}$, which is the most modern and best organised of those considered, with an olive storage area connected to the outside, but protected from the wind (PMV $=-0.48)$. The percentage of dissatisfied individuals (PPD) was clearly connected to the PMV values: the further away from conditions of thermal balance, the greater was the PPD.

The PMV indexes calculated for the oil extraction areas of the various oil mills were $<+0.5$ and therefore show a situation of comfort; the corresponding PPD percentages are all much lower than those for the olive storage areas with a value of $<10 \%$.

With the mean values of metabolic activity, ther- mal resistance of work clothing, air speed, relative humidity corresponding to the olive storage areas and the milling areas respectively, the trend of the PMV indexes was simulated on the basis of variations in air temperature $t_{a}$ and of mean radiating temperature $t_{g}$.

For both the above temperatures the following intervals were considered: $6 \div 12{ }^{\circ} \mathrm{C}$, for the olive storage areas; $12 \div 18{ }^{\circ} \mathrm{C}$ for the milling areas.

The result of these calculations is shown in the three dimensional graphs shown in Figure 8 where you can see the situation of thermal discomfort that develops in the olive storage areas, where the low temperatures create a feeling of cold of greater or lesser intensity (PMV values always lower than the thermal equilibrium).

The graph for the milling area (Fig. 8b) is very interesting. It shows the importance of the analyses of the microclimate of these work areas for the achievement of conditions of comfort and well-being; the surface representing the PMV indexes is between the negative and positive values of the window under examination.

The graph in Fig. 9, obtained taking the conditions of thermal neutrality (PMV $=0)$, shows that air temperature is closely linked to radiating temperature, and that, with the mean values registered for the various size areas under consideration, the optimum air temperature must be within the range $12 \div 15^{\circ} \mathrm{C}$.

\section{Conclusions}

The aim of the research was:

- recognition of the microclimatic values registered in the work areas during the extraction process in the more significant Apulian oil mills;

- the creation and fine-tuning of software for studying the conditions of global comfort in the working environments of these oil mills, based on the procedures of the technical Standard in force.

The results obtained from the surveys carried out in the mills studied show the importance of microclimate risk analyses in these environments, since the in-
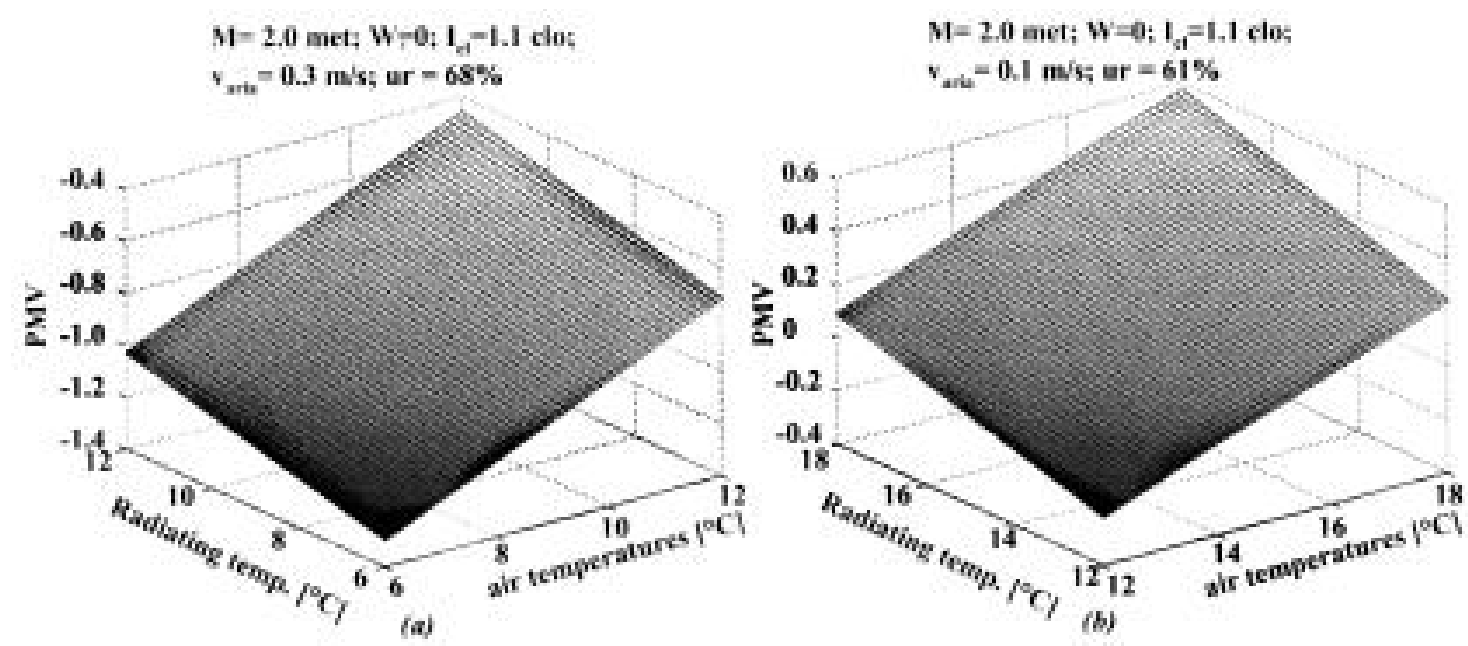

Fig. 8 - PMV graph based on typical parameters of the olive storage areas (a) and of the milling areas (b) 


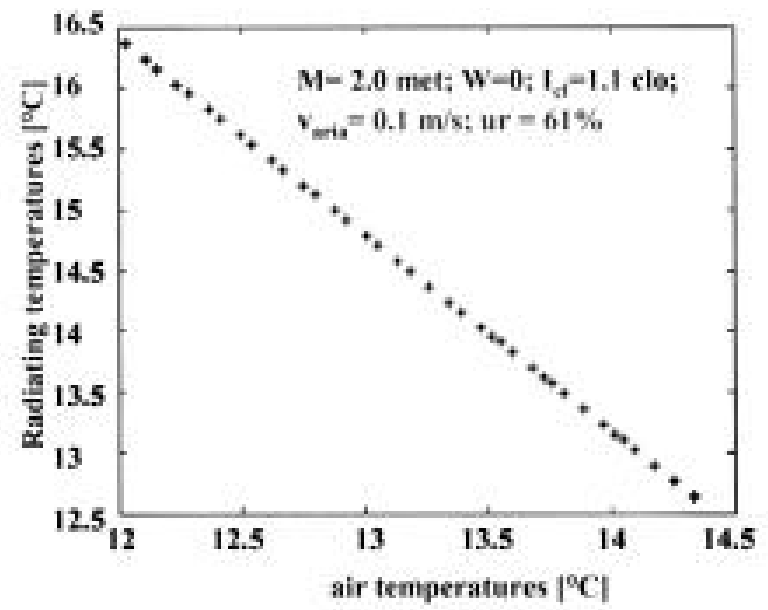

Fig. 9 - Relationship between air temperatures and radiating temperatures, in conditions of thermal neutrality $(\mathrm{PMV}=0)$.

strumental observations and consequent calculations have shown climatic conditions of discomfort in the olive storage areas. In the areas used for oil extraction, however, the data obtained shows acceptable conditions of thermal well-being; the data simulation carried out using the specific software allows us to affirm that the optimum temperature to create a sensation of comfort should be $12 \div 15^{\circ} \mathrm{C}$.

It should also be said, with reference to the oil mills studied, that the results obtained agree with what the workers declared, that they felt discomfort when they had to work in the olive storage area and when transferring the olives from the storage area to the internal working areas; furthermore, conditions of discomfort were generally found when moving between areas with different values of heat and humidity, and different air speeds.

The software created was useful, in planning new oil mills, for predicting the thermal sensations of the workers or, by measuring conditions using the instruments, for measuring the validity of complaints of discomfort by the workers in existing mills.

\section{References}

[1] Alfano G., La normativa vigente ed in preparazione nel campo del thermal comfort, Atti del Convegno dBA 2002.

[2] Blandini G., Garaffo S., La normativa italiana e comunitaria per gli impianti agro-industriali, Atti del Convegno Nazionale A.I.I.A. "La sicurezza delle macchine agricole e degli impianti agro-industriali", Alghero (SS), 11-15 settembre 2002, 277-283.

[3] Di Renzo G.C., Altieri G., D'Antonio P., D’Erchia L., La sicurezza nell'industria agro-alimentare, Atti del Convegno Nazionale A.I.I.A. "La sicurezza delle macchine agricole e degli impianti agro-industriali", Alghero (SS), 11-15 settembre 2002, 285-301.

[4] Carnahan B., Luther H.A., Wilkes J.O., Applied Numerical Methods, Wiley \& Sons, 1969.

[5] FAnger P.O., Thermal comfort. Analysis and Application in Environmental Engineering, Mc Graw Hill, New York, 1970.

[6] Monarca D., Porceddu R., Cecchini M., Babucci $\mathrm{V}$., La valutazione del rischio da microclima in ambi- enti di lavoro agroindustriali, Rivista di Ingegneria Agraria, (2005), 4, 89-93.

[7] LENZUNI P., La misurazione del comfort e del rischio: normative e valori di riferimento in ambienti termici moderati, Atti del Congresso dBA, Modena, 14 ottobre 2004, 35-51.

[8] Panaro V., Pascuzzi S., Santoro F., Analisi delle esposizioni al rumore nella filiera olivicola: rilievi nelle fasi di raccolta meccanica e spremitura delle olive, Rivista di Ingegneria Agraria, (2005), 2, 73-80.

[9] Panaro V., Pascuzzi S., SANTORo F., Analisi del rischio e misure di prevenzione nella filiera olivicola pugliese, Atti del Convegno Nazionale A.I.I.A. "La sicurezza delle macchine agricole e degli impianti agro-industriali", Alghero (SS), 11-15 settembre 2002, 323-334.

[10] Panaro V., Pascuzzi S., Santoro F., Rilievi e risultati di una ricerca biennale sui rumori nella filiera olivicola pugliese, Atti del Convegno Nazionale A.I.I.A. "La sicurezza delle macchine agricole e degli impianti agro-industriali", Alghero (SS), 11-15 settembre 2002, 391-402.

[11] Panaro V., Pascuzzi S., Santoro F., Criteri progettuali ai fini del contenimento del rumore all'interno di frantoi oleari, Atti del Convegno Nazionale A.I.I.A. "L'ingegneria agraria per lo sviluppo sostenibile dell'area mediterranea", Catania, 27-30 giugno 2005, CD-Rom Code 7003.

[12] Porceddu R., Monarca D., Cecchini M., Nelli S., La valutazione e la prevenzione del rischio da microclima in ambienti di lavoro agricoli e agroindustriali: indagine metodologica, Atti del VII Convegno Nazionale A.I.I.A. "Ingegneria Agraria per lo sviluppo dei Paesi del Mediterraneo", Vieste (FG), 11-13 settembre 2001, (disponibili su CD-ROM).

[13] Zoppello G., Rizzi C., Zucchiatti N., Gubiani R., Salute e sicurezza nella filiera lattiero-casearia: indagine nella regione Friuli Venezia Giulia, Atti del VII Convegno Nazionale A.I.I.A. "Ingegneria Agraria per lo sviluppo dei Paesi del Mediterraneo", Vieste (FG), 11-13 settembre 2001, (disponibili su CD-ROM).

[14] UNI EN ISO 7730, Ergonomia degli ambienti termici. Determinazione analitica e interpretazione del benessere termico mediante il calcolo degli indici PMV e PPD e dei criteri di benessere termico locale.

\section{SUMMARY}

Some oil mills, among the most representative in the Puglia Region in terms of quality and productivity have been considered, and the temperature and humidity of the environment and the sensations of temperature felt by the workers were registered inside them during the process of oil extraction.

Subsequently, a numerical code in MATLAB language was created, able to calculate the PMV and PPD and a study was carried out of the conditions of global comfort in the environment during the oil extraction process.

The results of the surveys carried out in the mills show the importance of microclimate risk analysis in these workplaces, since the instrumental surveys and the calculations have shown that climatic conditions are not comfortable in the olive storage bays. On the other hand, the data from the oil extraction areas shows an acceptable condition of thermal well-being.

Key words:

Olive mills, microclimate, working environments. 